\title{
Recent Advances in High-performance Functional Ceramics using 3D Nanostructuring Techniques
}

\author{
ChanguiAhn ${ }^{1}$, Junyong Park², Seokwoo Jeon ${ }^{3 \dagger}$
}

${ }^{1}$ Engineering Ceramic Center, Korea Institute of Ceramic Engineering and Technology, Icheon, Gyeonggi 17303, Republic of Korea ${ }^{2}$ School of Materials Science and Engineering,Kumoh National Institute of Technology, Gumi,Gyeongbuk39177, Republic of Korea ${ }^{3}$ Department of Materials Science and Engineering, KAIST Institute for The Nanocentury, KAIST, Daejeon 34141, Republic of Korea

\section{3차원 나노구조화 기술을 이용한 고성능 기능성 세라믹 연구개발 동향}

\author{
안창의 1 박준용 2 , 전석우 ${ }^{\dagger}$ \\ 1한국세라믹기술원 엔지니어링세라믹센터, 금오공과대학교 신소재공학부, ${ }^{3}$ 한국과학기술원 신소재공학과
}

(Received August 26, 2019; Accepted September 10, 2019)

\begin{abstract}
:
Functional ceramics are widely utilized in a variety of application fields such as structural materials, sensors, energy devices, purification filter and etc due to their high strength, stability and chemical activity. With the breakthrough development of nanotechnology, many researchers have studied new types of nanomaterials including nanoparticle, nanorod, nanowire and nanoplate to realize high-performance ceramics. Especially several groups have focused on the 3D nanostructured ceramics because of their large surface area, efficient load transfer, ultra-fast ion diffusion and superior electrical (or thermal) conductivity. In this review, we introduce the reported fabrication strategies of the 3D nanostructured and functional ceramics, also summarized the 3D nanostructured ceramic based highperformance applications containing photocatalysts, structural materials, energy harvesting and storage devices.
\end{abstract}

KYEWORDS: high-performance, functional ceramics, 3D nanostructures, outstanding materials properties

\section{1.서론}

현재까지 끊임없는 인간의 편리성 추구를 위해 항공 우주 - 자동차 - 전자 산업 등 다양한 분야에서 기능성 세 라믹 기반 신소재를 활용하려는 연구 개발이 지속적으로 이루어졌으며 실제 각 산업에서 고강도 소재, 방열소재,
전자파 차폐소재, 센서 소재로써 기능성 세라믹 재료가 적용되어왔다. 구체적인 예를 들면, 장식용 도자기와 극 한 환경용 항공기 터빈, 건물 외장재, 연마재 등 전통적 인 세라믹 소재 적용 분야를 포함하여 건강 및 미관용 인 공치아, 차량용 가스필터, 정수용 수 처리 필터, 디스플 레이용 투명 커버, 에너지 소자용 전극, 분리 막 등의 첨 


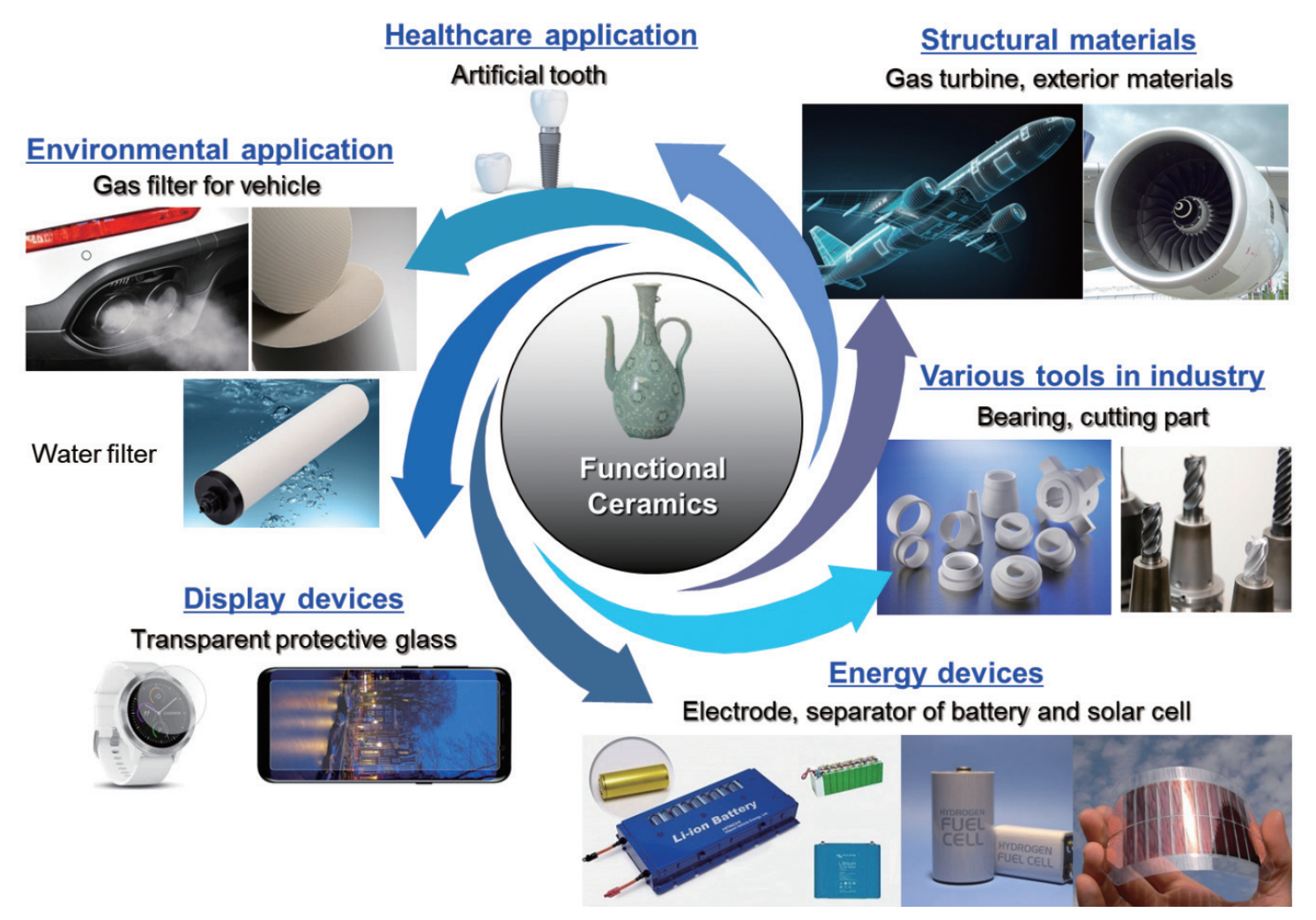

그림 1. 기능성 세라믹 소재들의 다양한 응용 분야

단 산업에도 광범위하게 기능성 세라믹 소재들이 활용되 고 있다. (그림1) 인간 삶 전반에 큰 영향을 주고 있는 기 능성 세라믹 소재들의 성능을 향상시키기 위한 연구 개발 은 오랫동안 진행되어 왔으며, 특히 1990년대 이후 나노 기술의 비약적 발전과 함께 마이크론 $\left(10^{-6}\right)$ 수준의 미세 영역에서 나노(10-9) 수준의 초미세영역으로 기능성 세라 믹 재료기술을 확장하여 기존 응용소재들의 성능을 뛰어 넘으려는 시도가 계속되고 있다. 단순히 크기만 나노미터 $(\mathrm{nm})$ 로 감소시키는 것이 아니라, 와이어, 로드, 판상 등 다양한 이방성 형태의 기능성 나노 세라믹 재료들을 제작 하여 소자 성능을 극대화하려는 연구가 중점적으로 진행 되고 있다. 앞서 언급한 이방성 세라믹 나노 재료들은 넓 은 비표면적, 이방성 재료들 간의 상대적으로 용이한 상 호 연결성 등의 장점들 때문에 고효율 센서, 에너지 전극 및 필터, 초고강도 복합소재 등으로 활용된다. 등방성(구 형 분말) 나노 소재보다 이방성 나노 세라믹 소재가 기존 소재보다 우수한 성능을 구현한 건 사실이지만, 복합소재
나 에너지소자 등의 응용소자에 적용시키기 위해서는 결 국에는 후공정을 통해 정형화(monolithic)된 형태의 구 조로 제작해야 하는데 나노 소재의 높은 부피 대비 표면 적 때문에 상호 간 응집되는 현상이 강하게 발생하여 쉽 게 제작하기 힘들다는 문제를 가지고 있다. 예를 들면, 에 너지 전극을 기능성 나노 소재로 만들면 전체적으로 개방 형 기공 구조를 가지는 것이 아니라, 많은 폐쇄형 기공 또 한 포함하게 됨으로 원활한 물질 전달(mass transport) 이 어려워 성능 향상에 제약이 존재하게 된다. 또한, 복 합소재 내에 형성되는 필러 재료가 기지상 내부에 균일하 게 분산되지 않거나 상호 연결되어 있지 않으면 이론적 성능 향상 수치에 크게 못 미치는 기계적, 열적, 전기적 물성을 나타내게 된다.

위의 문제를 해결하기 위해 주목받고 있는 접근 방식으 로서 2010년대부터 3차원 방향으로 정렬되어 있고 상호 연결성이 우수한 기능성 세라믹 나노재료를 에너지 전극, 구조 소재, 센서 등 다양한 응용분야에 접목하려는 연구 
특 집 ㅁㅁ안창의, 박준용, 전석우

\begin{tabular}{|c|c|c|c|c|c|}
\hline & 재료 & 제조가능면적 & 속도 & 분해능 & 특징 \\
\hline $\begin{array}{c}\text { Colloidal } \\
\text { self-assembly }\end{array}$ & 고분자, 무기입자 & 6 inch $\times 6$ inch & $\begin{array}{l}\text { seconds to } \\
\text { days }\end{array}$ & $<100 \mathrm{~nm}$ & $\begin{array}{c}\text { 자연발생적 결함, } \\
\text { 낮은 재현성 및 생산성 }\end{array}$ \\
\hline $\begin{array}{l}\text { Direct ink } \\
\text { writing }\end{array}$ & $\begin{array}{c}\text { 고분자, } \\
\text { 무기 입자 함유 젤 }\end{array}$ & 4 inch $\times 4$ inch & $250 \mu \mathrm{m} / \mathrm{s}$ & $\sim 1 \mu \mathrm{m}$ & $\begin{array}{l}\text { 높은 분해능, } \\
\text { 낮은 생산속도 }\end{array}$ \\
\hline $\begin{array}{l}\text { Multi-beam } \\
\text { Interference } \\
\text { lithography }\end{array}$ & $\begin{array}{l}\text { 감광성 고분자, } \\
\text { 유무기 혼합 소재 }\end{array}$ & 4 inch $\times 4$ inch & $\begin{array}{l}\text { ns to } \\
\text { seconds }\end{array}$ & $\sim 300 \mathrm{~nm}$ & $\begin{array}{l}\text { 환경(진동 등)에 대한 } \\
\text { 높은 민감성 }\end{array}$ \\
\hline $\begin{array}{l}\text { Proximity field } \\
\text { nanoPatterning }\end{array}$ & $\begin{array}{l}\text { 감광성 고분자, } \\
\text { 유무기 혼합 소재 }\end{array}$ & 4 inch $\times 4$ inch & $\begin{array}{l}\text { ns to } \\
\text { seconds }\end{array}$ & $<300 \mathrm{~nm}$ & $\begin{array}{c}\text { 위상마스크와 빔 조사면적에 } \\
1: 1 \text { 매칭되는 제작면적 }\end{array}$ \\
\hline
\end{tabular}

표 1. 개발된 3차원 구조화 기술들

들이 진행되기 시작했다. 대표적인 3차원 나노 구조화 기 술은 Direct ink writing, Colloidal self-assembly, Multi-beam interference lithography (MBIL), Proximity-field nanoPatterning( $\mathrm{PnP})$ 기술이 있으 며, 각 기술에 대한 비교는 표1에 정리되어 있다. 이 기술 들에 대해 간략히 설명하자면 Direct ink writing은 고분 자나 무기 입자가 함유된 젤을 노즐을 통해 압출 시켜주 고 이를 그림 그리듯이 3 차원 구조를 제작하는 기술로써 원하는 형상을 자유롭게 패터닝 할 수 있으나 제작 가능 한 분해능이 마이크로미터 수준으로 높고, 생산속도가 느 리다는 문제를 가지고 있다.)(그림2a) Colloidal selfassembly는 구형의 유·무기 나노입자를 층층이 쌓아
올려 정렬된 3차원 나노 구조를 제작하는 방법으로 구성 이 용이하지만 입자 적층 시 발생하는 자연적 결함률이 높고, 재현성이 낮은 단점이 있다. ${ }^{2}$ (그림 2b) MBIL는 결 맞는 여러 개의 빔을 동시에 조사하여 발생하는 보강간 섭, 상쇄간섭을 통해 빛의 3 차원 분포를 형성하고 이를 감광성 고분자에 전사시켜 3차원 나노 구조를 제작 방법 으로 낮은 결함률을 나타내는 기술이다. ${ }^{3)}$ (그림2c) $\mathrm{PnP}$ 기술은 MBIL의 광학계를 위상 마스크(phase mask)라 는 구성요소에 집약하여 진동 등의 환경적인 요소에서 안 정적으로 3차원 나노 구조를 제작하는 방법이다. ${ }^{4), 5)}$ 간단 히 공정에 대해 소개하자면, 여러 개의 빔이 아닌 하나의 빔을 위상 마스크에 조사하고, 투과된 빛은 주기적인 나

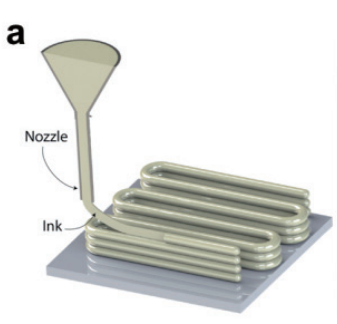

C

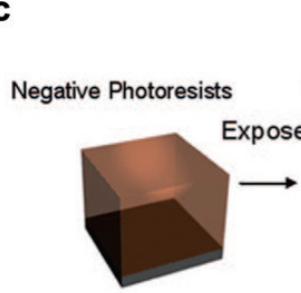

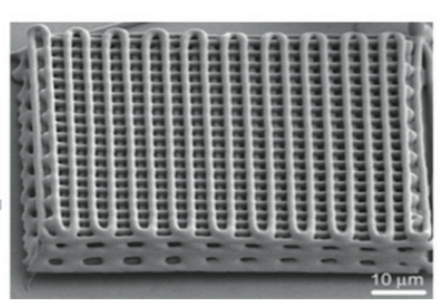
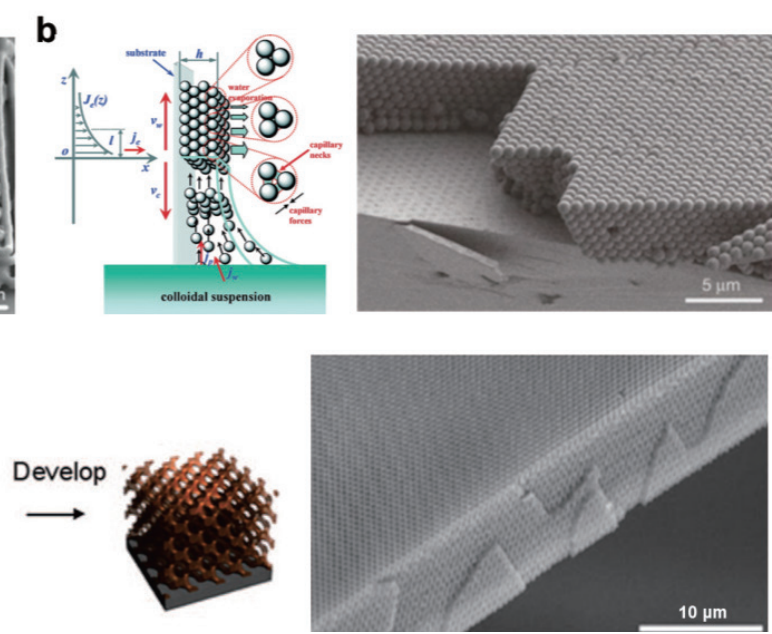

그림 2. (a)Direct ink-writing, (b) colloidal self-assembly, (c) multi-beam interference lithography의 공정도 및 제작된 3차원구조체 ${ }^{1-3}$ 


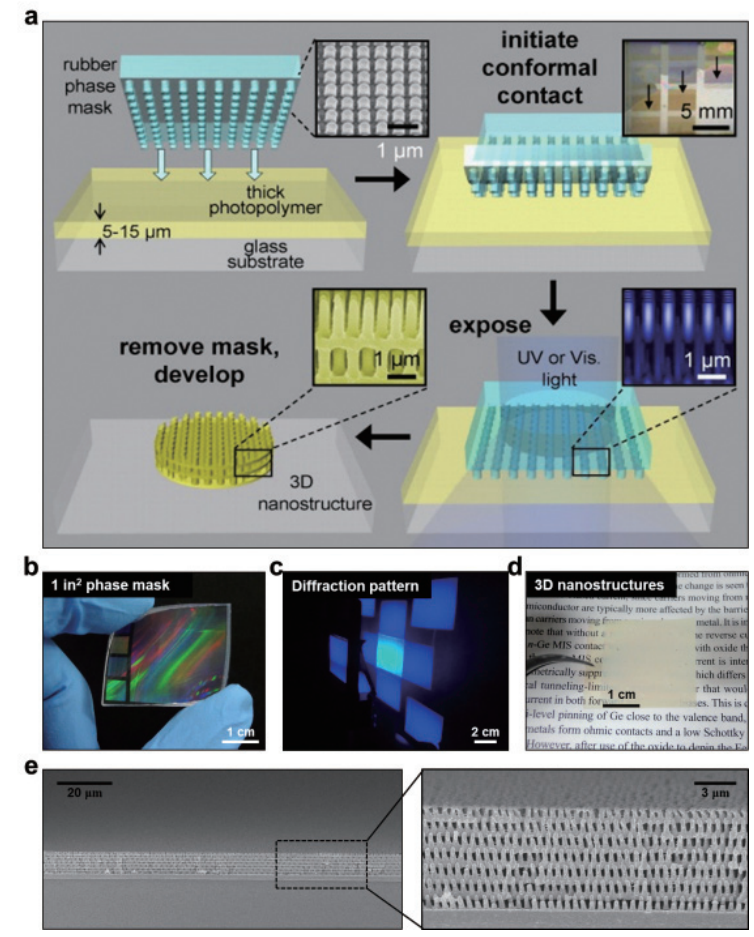

그림 3. 근정장나노패터닝기술의 (a) 제작공정및 $(\mathrm{b}, \mathrm{c})$ 구성요소, (d, e) 제작된 3차원나노구조노

노기둥 구조를 가진 투명 위상 마스크에 의한 회절 및 간 섭현상을 통해 3 차원의 주기적인 빔 분포를 마스크 아래 에서 형성하게 되고 이를 감광성 물질로 전사하여 3차원 나노 구조를 제작하게 된다. (그림 3) 위 기술들은 다양한 3 차원 나노 구조를 제작할 수 있지만, 제작 가능한 소재 의 범위가 고분자에 한정되어 있기 때문에 3 차원 나노 구 조의 기능성 세라믹 소재를 구현하기 위해서는 주조공정 과 유사한 템플레이팅(templating) 기술 또한 필요하다. 템플레이팅 기술은 위의 방법들로 제작된 3차원 나노 구 조의 고분자 주형 내부에 원하는 기능성 소재를 함침 시

\begin{tabular}{cc} 
Materials & Methods \\
\hline $\mathrm{Al}_{2} \mathrm{O}_{3}$ & Atomic layer deposition, Electroplating \\
$\mathrm{TiO}_{2}$ & Atomic layer deposition, Electroplating \\
$\mathrm{ZnO}$ & Atomic layer deposition, Electroplating \\
$\mathrm{SnO}_{2}$ & Atomic layer deposition, Electroplating \\
$\mathrm{Cu}_{2} \mathrm{O}$ & Electroplating
\end{tabular}

표 2. 대표적 기능성세라믹 소재들과 3 차원 나노구조 내부로의 함침방법들

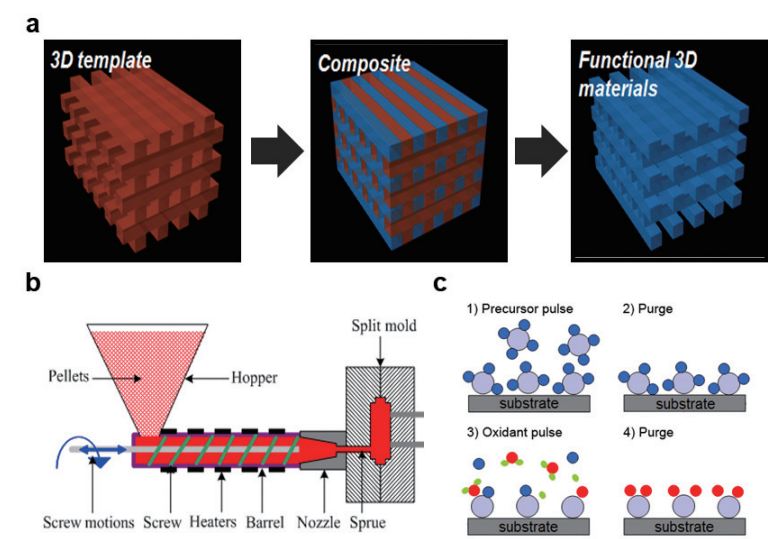

그림 4. (a) 템플레이팅기술을 이용한 기능성 세라믹소재의 3차원 나노구조화공정, (b) 세라믹분말용액의 함침방법, (c) 원자 층증착법의 공정순서 ${ }^{6}$

키고 템플릿을 선택적으로 제거함으로써 역상의 3차원 나노 구조의 기능성 소재를 제작하는 것이다. 특히, 기능 성 세라믹 소재를 3 차원 나노 구조의 주형에 함침 시키기 위한 대표적인 기술들로는 세라믹 나노분말을 용매에 섞 어 기공에 침투시키는 용액공정과 기상 전구체(precursor) 를 이용하여 원자 한 층씩 표면에 증착 시키는 원자층 증 착법(atomic layer deposition, ALD)이 있다. ${ }^{6}$ (그림4 b, c) 대표적 기능성 세라믹 소재와 함침 방법에 대해서는 표 2에 정리하였다. 함침 공정 후 고분자 주형의 선택적 제거 방법으로는 고온 열처리 $\left(400^{\circ} \mathrm{C}\right)$ 나 플라즈마를 이용한 에 칭 방법을 이용한다.

이번 총설에서는 3 차원 나노 구조화 기술을 이용한 기 능성 세라믹 소재를 제작하고 이를 실제 광촉매, 구조 소 재, 에너지 생산 소재에 적용한 최신 연구 개발 동향에 대 해 정리하고자 한다.

\section{2. 본론}

\section{1. 유기오염원 제거용 광촉매소재}

최근 큰 이슈였던 미세먼지로 대표되는 환경오염 문제 는 인간이 반드시 해결해야 할 문제로 인식됨에 따라 오 염원들을 제거하는 기술에 대한 연구개발이 학계, 연구 계, 산업계에서 동시다발적으로 진행되고 있다. 특히, 자 연광을 이용하는 친환경적이고 반영구적 유기 오염원 제 
특 집 ㅁㅁ안창의, 박준용, 전석우

거 방식인 광촉매 소재를 활용하는 기술이 각광받고 있으 나, 낮은 유기오염원 분해 효율과 재사용성 문제로 이를 해결하기 위한 연구개발이 필요하다. 2.1. 절에서는 3차 원 나노 구조의 세라믹 소재를 활용한 고성능의 광촉매 소재의 개발 동향에 대해 설명하고자 한다.

\subsection{1. $3 \mathrm{D} \mathrm{TiO}_{2}$ 기반 광촉매}

전석우 교수 연구팀은 $\mathrm{PnP}$ 기술과 $\mathrm{ALD}$ 를 이용하여 유 기오염원 제거용 3 차원 나노 구조의 $\mathrm{TiO}_{2}$ 광촉매 소재에 대한 연구결과를 보고 하였다. ${ }^{7)}$ 제조공정에 대해 설명하 자면, 앞서 소개한 $\mathrm{PnP}$ 기술을 이용하여 3차원 나노 구 조의 에폭시 주형을 제작하고, 저온 $\left(\left\langle 100{ }^{\circ} \mathrm{C}\right)\right.$ 에서 $\mathrm{TiO}_{2}$ 를 구조체 표면에 $80 \mathrm{~nm}$ 이하로 얇게 코팅한다. (그림5a) 고 분자 주형이기 때문에 $100^{\circ} \mathrm{C}$ 이상의 온도에서는 구조체 가 무너지는 현상이 발생하므로 때문에 상대적으로 낮은 온도에서 $\mathrm{TiO}_{2}$ 를 증착할 수 있는 $\mathrm{ALD}$ 기술을 통해 증착
한다. 하지만 낮은 온도에서 공정이 진행되는 $\mathrm{ALD}$ 공정 의 특성상 증착되는 $\mathrm{TiO}_{2}$ 는 비정질(amorphous)로 형성 되게 되는데 이는 광촉매 내에 유기물 제거를 위해 활용 되는 electron과 hole의 재결합율을 높여 광촉매 성능에 치명적인 영향을 주게 되고 이를 해결하기 위해 광촉매 성능이 가장 우수하다고 보고된 아나타제(anatase) 상으 로 변환시킬 수 있는 방법이 필요하다. 비정질의 $\mathrm{TiO}_{2}$ 는 공기 분위기에서 $400^{\circ} \mathrm{C}$ 이상의 열처리로 아나타제상으 로 상변이 시킬 수 있고 동시에 에폭시 주형을 선택적으 로 제거할 수 있다. 연구팀은 고온 열처리 중의 급격한 상 변화와 에폭시 주형 제거에 따른 급격한 부피 손실에 의 한 3차원 나노 구조체의 무너짐 현상을 방지하기 위해 승 온 속도를 조절하는 방법을 이용하였다. 이를 통해 제작 한 3 차원 나노 구조의 $\mathrm{TiO}_{2}$ 광촉매 소재는 메틸렌블루 (methylene blue, MB) 유기 안료가 분산된 용액에서 배 치시키고 자외선을 조사함으로써 광촉매 성능을 보고했 a
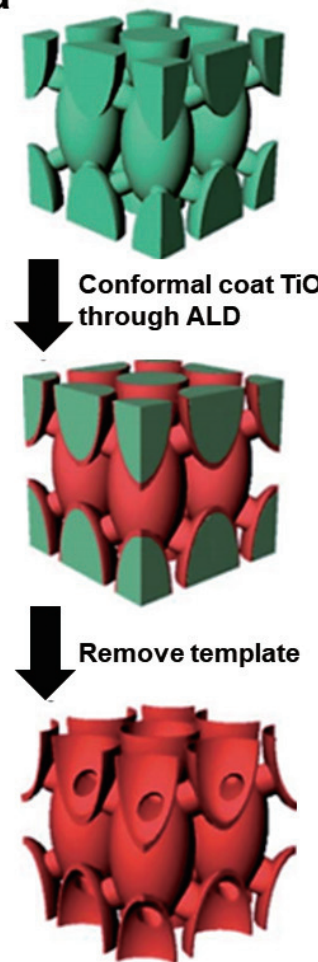
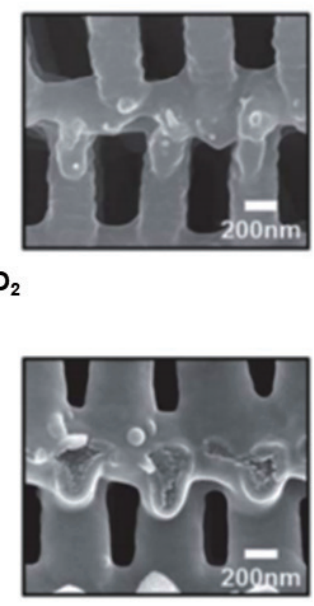

b

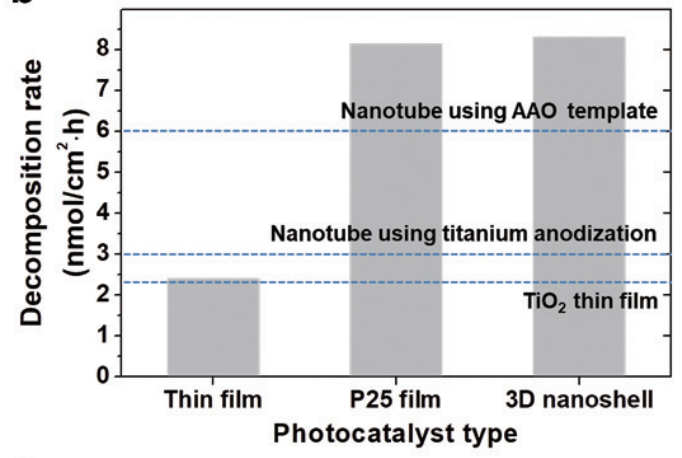

C

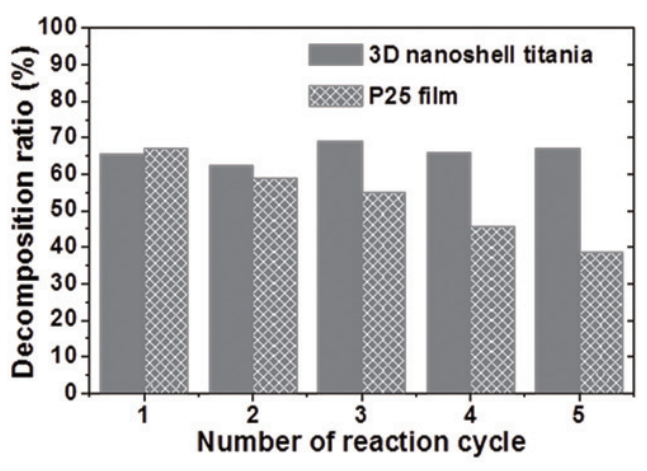

그림 5. $3 \mathrm{D} \mathrm{TiO} \mathrm{O}_{2}$ 기반광촉매소재. (a) $\mathrm{PnP}$ 기술과 $\mathrm{ALD}$ 기술을 이용한 $3 \mathrm{D} \mathrm{TiO}_{2}$ 제작공정모식도, (b) 기존에 보고된 나노구조의 $\mathrm{TiO}_{2}$ 와의 광촉 매성능비교, (c) 재사용에 따른 광촉매 성능 7 
a

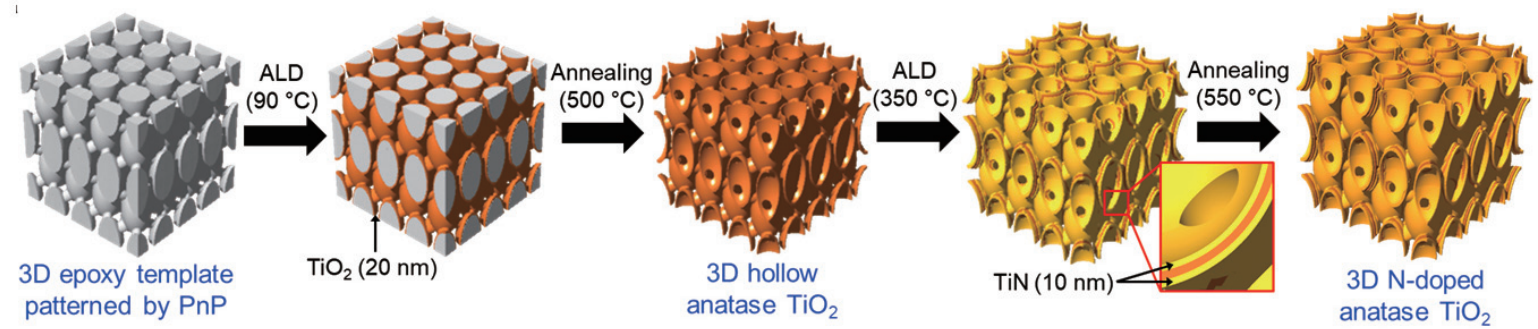

b

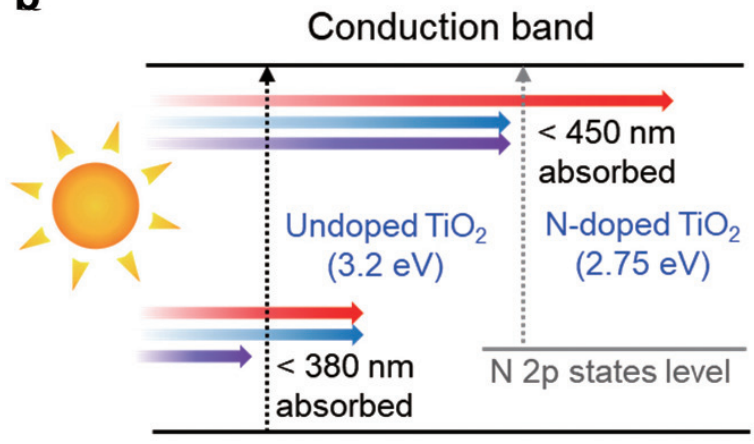

Valence band
C

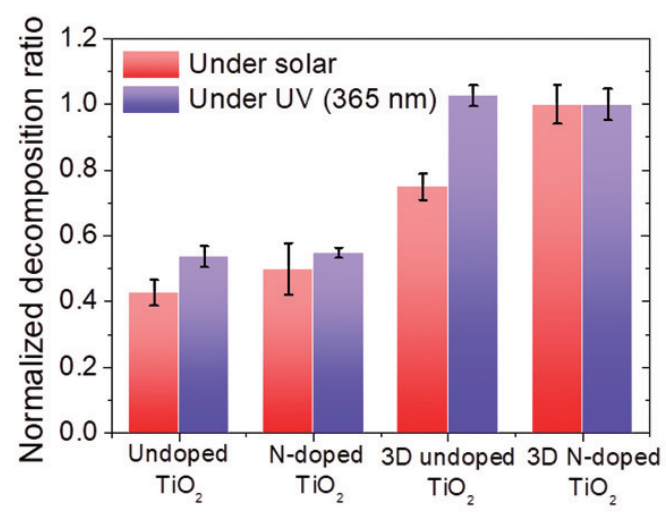

그림 6. $3 \mathrm{D} \mathrm{N}$-doped $\mathrm{TiO}_{2}$ 기반 가시광 반응용 광촉매. (a) $3 \mathrm{D} \mathrm{N}$-doped $\mathrm{TiO}_{2}$ 광촉매 제작 공정 모식도, (b) $\mathrm{TiO}_{2}$ 와 N-doped $\mathrm{TiO}_{2}$ 광촉매의 밴드갭 모식도, (c) $\mathrm{TiO}_{2}$ 와 $\mathrm{N}$-doped $\mathrm{TiO}_{2}$ 의 자외선과 태양광 조사하에서의 광촉매 성능 9

다. 3 차원 나노 구조의 $\mathrm{TiO}_{2}$ 의 광촉매 성능을 박막, 상용 입자(P25), 이전에 보고된 나노 튜브 형태의 $\mathrm{TiO}_{2}$ 들과 비 교한 결과를 보면 3 차원 $\mathrm{TiO}_{2}$ 광촉매는 박막보다 2.5 배, 상용 입자와 비슷한 성능을 보이며, 이전에 보고된 나노 튜브 형태의 $\mathrm{TiO}_{2}$ 보다 우수한 광촉매 성능을 보이는 것 을 나타낸다. (그림5b) 이 결과는 3 차원 나노 구조의 넓은 비표면적, 광산란효과 때문에 나타난다고 보고하고 있 다. 또한, 기존 나노 입자 형태의 $\mathrm{TiO}_{2}$ 광촉매의 재사용 을 위해서는 원심분리기를 이용한 회수 과정이 필요하나, 보고된 3차원 $\mathrm{TiO}_{2}$ 는 정형화된(monolithic) 광촉매이므 로 성능 저하 없고 회수 과정 없는 재사용성이 우수한 광 촉매임을 증명했다.

\subsubsection{D N-doped $\mathrm{TiO}_{2}$ 기반 가시광 반응용 광촉매}

$\mathrm{TiO}_{2}$ 는 높은 광촉매 활성 및 광안정성을 가지고 있지 만, 재료 자체의 높은 밴드갭( $3.2 \mathrm{eV})$ 때문에 $400 \mathrm{~nm}$ 파 장 이하의 자외선 조사 하에서만 광촉매 활성이 나타나는
문제를 가지고 있다. 태양광에서 $400 \mathrm{~nm}$ 파장 이하의 자 외선은 $10 \%$ 밖에 되지 않기 때문에 흡수하고 활용할 수 있는 빛의 파장을 가시광 영역까지 확장해야 하며 이를 위해서는 $\mathrm{TiO}_{2}$ 광촉매의 밴드갭을 줄여야 한다. 특히, 앞 절에서 언급한 3 차원 나노 구조의 우수한 성능을 유지하 면서 가시광 영역까지 광 흡수 효과를 추가하여 고성능의 광촉매를 구현하는 전략이 필요하다. ${ }^{8)}$

전석우 교수 연구팀은 위의 방법과 유사한 접근법을 통 해 3차원 나노 구조의 $\mathrm{N}$ 도핑 된 $\mathrm{TiO}_{2}$ 를 제작하고 태양 광 조사 하에서의 광촉매 성능을 보고하였다. ${ }^{9} \mathrm{PnP}$ 기술 을 이용하여 3 차원 구조의 에폭시 주형을 제작한 후 저온 $\left(90^{\circ} \mathrm{C}\right)$ 에서 $\mathrm{TiO}_{2}$ 를 형성 시키고 주형을 제거하여 3 차원 나노 구조의 $\mathrm{TiO}_{2}$ 를 제작하는 공정까지는 동일한 방법으 로 진행되었다. 그 이후 공정에서는 3 차원 나노 쉘 (nanoshell) 구조에 상대적으로 고온 $\left(350^{\circ} \mathrm{C}\right)$ 분위기에서 $\mathrm{TiN}$ 을 $10 \mathrm{~nm}$ 두께로 쉘 양쪽에 균일하게 $\mathrm{ALD}$ 를 통해 증 착 시키고 $550^{\circ} \mathrm{C}$ 에서 열처리를 통해 증착된 $\mathrm{TiN}$ 를 산화 
시킴으로써 $\mathrm{N}$ 도핑된 3 차원 나노 구조의 $\mathrm{TiO}_{2}$ 를 제작하 는데 성공했다. (그림6a) 위의 방법으로 제작된 $\mathrm{N}$ 도핑된 $\mathrm{TiO}_{2}$ 와 도핑되지 않은 $\mathrm{TiO}_{2}$ 의 밴드갭을 측정했을 때 밴 드갭은 $3.2 \mathrm{eV}$ 에서 $2.75 \mathrm{eV}$ 로 감소했고 흡수할수 있는 파 장역역이 $450 \mathrm{~nm}$ 로 증가한 결과를 보고했다. (그림6b) 앞 서 보고한 광촉매 성능 검사 방법과 동일한 메틸렌블루 안료의 분해로 성능을 비교 분석한 결과는 자외선 조사 하에서는 성능 변화가 없었지만 태양광 조사 하에서는 가 시광 영역에서의 흡수율 증가 때문에 도핑 된 3차원 나노 구조의 $\mathrm{TiO}_{2}$ 가 도핑 되지 않은 $\mathrm{TiO}_{2}$ 보다 우수한 광촉매 활성을 나타낸다는 것을 증명했다. 흡수되는 광자의 양이 증가함에도 불구하고 자외선 영역에서의 성능 변화가 없 는 것은 $\mathrm{N}$ 도핑 된 $\mathrm{TiO}_{2}$ 의 결함 수의 증가에 따라 재결합 되는 전자와 정공의 재결합률이 높기 때문이라고 설명하 고 있다.

\section{2 고강도 구조 소재}

구조 소재는 기존 세라믹이 활용되어온 전통적 응용분 야이며, 항공기 터빈, 건물 외장재뿐만 아니라, 최근에는 모바일 기기, 자동차 등 최첨단 산업에도 가벼우면서도
고강도를 갖는 세라믹 기반 소재를 적용하려는 시도가 계 속되고 있다. 특히, 미래 기술로써 경량 - 고강도 단일 세 라믹 소재와 최소화된 세라믹 필러 소재 첨가에도 강도를 극대화할 수 있는 고분자복합소재에 큰 관심이 집중되고 있다. 2.2. 절에서는 3 차원 나노 구조의 세라믹을 이용하 여 구조 소재에 대한 위 두 가지 연구개발 동향에 대응하 는 접근 방식에 대해 소개하고자 한다.

\subsubsection{D 세라믹 구조체 기반 경량 고강도 소재}

세라믹을 이용한 전통적인 구조 소재는 높은 강도를 나 타내지만 높은 밀도 $\left(3 \mathrm{~g} / \mathrm{cm}^{3}\right)$ 로 인해 미래 기술의 핵심 요소인 경량화 이슈에 기존 기술들로 대응하기에는 한계 가 있다. 따라서 최근에는 나노 구조체의 특수한 기계적 거동과 결함 존재 확률의 최소화 등의 새로운 접근 방식 을 통해 세라믹 소재를 미래 구조 소재 기술에 적용하려 는 연구가 진행되고 있다. 이 절에서는 3차원적으로 정렬 되어 있는 $\mathrm{TiN}$ 와 $\mathrm{Al}_{2} \mathrm{O}_{3}$ 나노 구조체를 이용하여 낮은 밀 도에서 고강도 구조 소재를 구현한 대표적 연구들을 소개 하고자 한다.

Julia greer 교수 연구팀은 3차원 나노 튜브 형태의 a

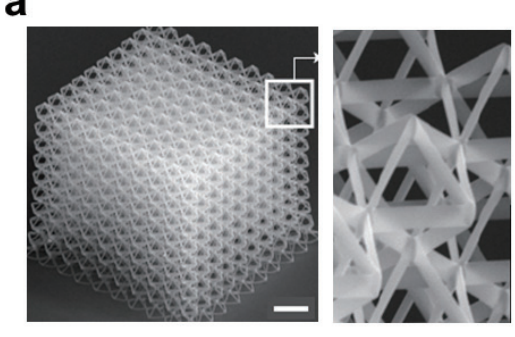

b

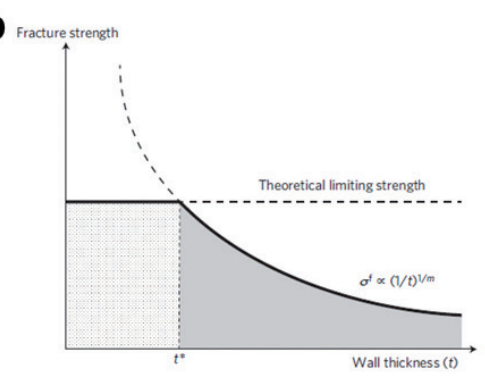

C

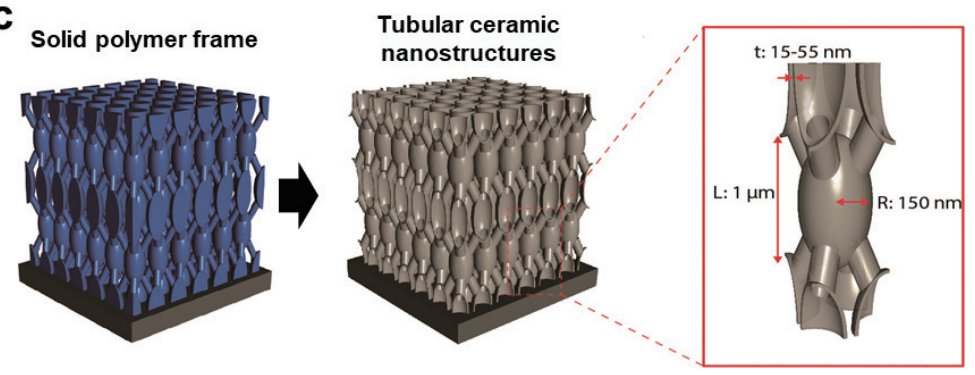

d

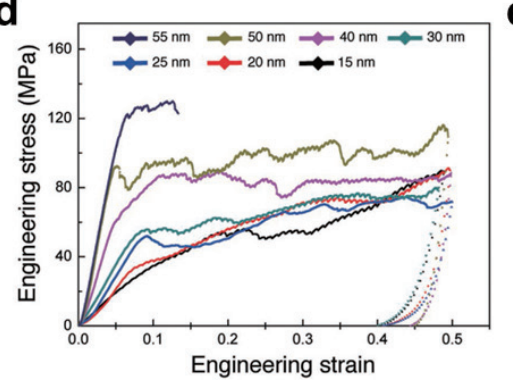

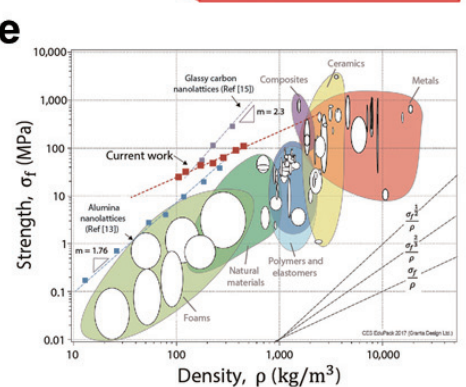

그림 7. 3D 세라믹 기반 경량 고강도 소재.(a) 3D 나노튜브 구조의 TiN SEM 이미지(scale bar: $5 \mu m$ ), (b) 파괴응력과 쉘 두께에 대한 weibull 분포, (c) $3 \mathrm{D}$ 나노튜브 구조의 $\mathrm{Al}_{2} \mathrm{O}_{3}$ 제작공정 및 단위셀, (d) 쉘 두께에 따른 $3 \mathrm{D} \mathrm{Al}_{2} \mathrm{O}_{3}$ 의 응력 변화, (e) $3 \mathrm{D} \mathrm{Al}_{2} \mathrm{O}_{3}$ 의 밀도대비 강도가 표시된 에쉬비 플롯(ashby plot) ${ }^{10-11}$ 
$\mathrm{TiN}$ 구조체를 제작하여 경량 - 고강도 구조소재를 제작 하고 기계적 거동을 분석한 연구결과를 보고하였다. ${ }^{10)}$ Direct laser writing(DLW) 기법을 이용하여 3차원 나 노 구조의 고분자 재료를 제작한 후, $\mathrm{ALD}$ 를 이용해 $140^{\circ} \mathrm{C}$ 에서 $\mathrm{TiN}$ 를 균일하게 코팅하고 플라즈마 기반 에 칭법을 활용하여 고분자만 선택적으로 제거함으로써 3차 원 나노 튜브 구조의 $\mathrm{TiN}$ 를 제작하는데 성공했다. (그림 $7 \mathrm{a}$ ) 제작된 3 차원 $\mathrm{TiN}$ 나노 구조체는 이론적 $\mathrm{TiN}$ 재료 의 강도의 $1 / 2$ 정도 수준인 $1.75 \mathrm{GPa}$ 이라는 기존에 보고 된 동일 소재 중 가장 높은 값을 나타냈다. 일반적으로 벌 크 수준의 소재는 자연적으로 내재되어 있는 결함에 의해 이론적인 강도 값에 크게 못 미치는 수치를 낸다고 알려 져 있지만 이 연구결과는 이를 극복할 수 있는 접근 방식 중 하나를 제시했다는데 큰 의미가 있다. 우수한 기계적 강도 결과에 대해 Greer 교수 연구팀은 구조적인 요인과 결함 존재 확률에 의해 이루어진 것이라고 분석하고 있 다. Brittle한 벌크 세라믹 소재는 응력이 가해지면 금방 파괴가 일어나게 되지만 주기적 나노 구조체에서 응력이 가해지면 구조체의 노드(node) 부분에서 회전 거동이 일 어나 높은 변위에도 견딜 수 있고, 또한, 나노 수준으로 소재를 제작하게 되면 결함이 존재할 확률이 비약적으로 감소하게 되어 이론적인 값에 근접한 강도를 가지는 세라 믹 구조재료를 제작할 수 있다는 것을 시뮬레이션 및 통 계적 분석을 통해 증명했다. (그림7b)

장동찬 교수 연구팀은 3차원적으로 정렬되어 있는 튜 브 형태의 $\mathrm{Al}_{2} \mathrm{O}_{3}$ 나노 구조체를 제작하여 경량 - 고강도 구조소재에 대한 연구결과를 보고하였다. ${ }^{11}$ 제작된 고분 자 주형에 $\mathrm{Al}_{2} \mathrm{O}_{3}$ 를 코팅한 후, 주형을 선택적으로 제거하 여 3차원 튜브 형태의 $\mathrm{Al}_{2} \mathrm{O}_{3}$ 를 제작했다. 제작된 3 차원 구조체는 기판에 수평 및 수직 방향으로 각각 $400 \mathrm{~nm}$, $2 \mu \mathrm{m}$ 의 주기성을 가지는 단위 셀(unit cell)로 전면적에 정렬되어 있으며, 튜브의 쉘 두께는 밀도 조절을 위해 $15 \mathrm{~nm} \sim 55 \mathrm{~nm}$ 까지 $\mathrm{ALD}$ 를 통해 미세하게 조절하여 제작 했다. (그림7c) 일반적으로 다공성 구조체는 기공이 없는 순수한 벌크 소재에 대비해서 아래와 같은 관계를 가진다 고 알려져 있다.

$$
\sigma_{f}=\sigma_{0}(\tilde{\rho})^{m}
$$

$\sigma_{f,} \sigma_{0}, \tilde{\rho}$ 는 각각 다공성 구조체의 강도, 벌크 재료의 강도와 상대밀도를 나타낸다. 다공성 구조체는 벌크 재료 대비 상대밀도가 낮아짐에 따라 강도가 감소하게 되는데, 감소 정도는 지수인 $m$ 의 값에 의해 결정되게 되며, $m$ 값 은 다공성 소재의 구조적인 요인에 의해 결정되는 수치이 다. 따라서 더 낮은 $\mathrm{m}$ 값을 구현할 수 있는 다공성 구조 체는 낮은 밀도에서도 높은 강도 값을 나타낼 수 있다. 기 존 다공성 구조 소재는 대부분 1.5 이상의 $\mathrm{m}$ 값을 나타냈 지만 장동찬 교수 연구팀에서 보고한 3차원 나노 튜브 형 태의 $\mathrm{Al}_{2} \mathrm{O}_{3}$ 는 0.93 이라는 아주 낮은 수치를 보여줌으로 기계적 강도 손해를 최소화하면서 경량 소재를 구현할 수 있는 방법이라고 보고 하고 있다. (그림 $7 \mathrm{~d}, \mathrm{e}$ )

\subsection{2. $3 \mathrm{D} \mathrm{Al}_{2} \mathrm{O}_{3}$ 기반 고강도 고분자복합소재}

일반적인 복합소재의 기계적 강도는 아래와 같은 rule of mixture라는 간단한 방정식으로 정의되어왔다.

$$
\sigma_{c}=V_{m} \sigma_{m}+V_{f} \sigma_{f}
$$

$\sigma_{c}, \sigma_{m}, \sigma_{f}$ 는 각각 복합소재(composite), 기지상 (matrix), 필러(filler)의 강도를 나타내고, $V_{m}, V_{f}$ 는 각각 기지상과 필러의 부피 분율을 나타낸다. 즉, 기지상과 필 러의 비율 및 강도에 따른 비례식에 의해 이론적인 복합 소재의 기계적 강도 값이 산출된다는 뜻이다. 이에 따라 그래핀과 탄소나노튜브 등 초고강도의 필러 재료를 이용 하여 우수한 성능의 고분자 복합소재를 구현하려는 시도 가 계속되어 왔지만 나노소재들은 높은 부피 대비 표면적 때문에 기지상 내에서 서로 응집하려는 경향 때문에 균일 한 분산이 어려워 나노입자 형태의 필러 재료로는 대부분 $5 \mathrm{vol} \%$ 이하에서만 강도 강화 효과를 나타내고 그 이상에 서는 응력집중 효과 때문에 오히려 기계적 물성이 퇴화하 는 문제가 발생했다. 3 차원 방향으로 전면적에서 상호 연 결되어있고 정렬되어 있는 세라믹 나노 구조체는 위에서 설명한 단일 소재의 구조재료뿐만 아니라, 고분자 복합소 재에서도 기계적, 열적, 전기적 특성을 극대화할 수 있는 
전략 중 하나이다. 정렬된 3차원 나노 구조의 세라믹 재 료를 고분자 복합소재의 필러 재료로 활용할 경우 높은 분산성과 연결성을 확보할 수 있어 이상적인 고강도 복합 소재를 구현할 수 있다. 이 절에서는 3 차원 나노 구조의 $\mathrm{Al}_{2} \mathrm{O}_{3}$ 를 필러 재료로 활용한 고분자 복합소재에 대한 연 구를 소개하고자 한다.

전석우 교수 연구팀은 에폭시 고분자 기지상에 전면적 에서 3차원으로 상호 연결되어 있고 정렬되어 있는 $\mathrm{Al}_{2} \mathrm{O}_{3}$ 재료를 형성시켜 고강도의 복합소재를 제작하고 메커니 즘에 대해 분석한 연구를 보고했다. ${ }^{2)} 3$ 차원 나노 구조의 에폭시 고분자를 제조한 후 $\mathrm{ALD}$ 를 이용하여 구조체 표 면에 $12 \mathrm{~nm}, 36 \mathrm{~nm}, 60 \mathrm{~nm}, 84 \mathrm{~nm}$ 두께의 $\mathrm{Al}_{2} \mathrm{O}_{3}$ 를 $\mathrm{ALD}$ 를 이용해 균일하게 증착하고, 동종의 에폭시 수지를 남 아있는 기공에 침투시켜 에폭시 사이에 $\mathrm{Al}_{2} \mathrm{O}_{3}$ 필러 재료 가 형성되어 있는 새로운 개념의 복합소재를 제작했다. (그림 $8 \mathrm{a}$ ) 보고된 3 차원 $\mathrm{Al}_{2} \mathrm{O}_{3} /$ 에폭시 복합소재는 기존 복합소재와는 다르게 $20 \mathrm{vol} \%$ 까지 필러를 첨가했을 때 rule of mixture 방정식에 의해 계산된 이론 수치와 일치 하는 압축 강도 값을 나타내었다. 이와 같은 이상적인 복 합소재의 강화 효과의 원인을 분석하기 위해 유한 요소해 석 기술을 이용하여 압축응력이 주어졌을 때 응력분포를 확인했고, 3 차원 방향으로 정렬되고 연결되어있는 $\mathrm{Al}_{2} \mathrm{O}_{3}$ 필러 재료 때문에 복합소재내에 부가되는 응력이 고분자
기지상에서 강한 $\mathrm{Al}_{2} \mathrm{O}_{3}$ 필러로 효율적으로 전달됨으로써 강화효과를 극대화할 수 있었다고 보고하고 있다. (그림 $8 \mathrm{c})$ 특히, 이런 효율적인 응력 전달은 복합소재의 기지상 과 필러에 동등한 응력이 작용하는 iso-stress 거동이 아 닌 동등한 변위 변화를 하는 iso-strain 조건에서 복합소 재가 거동하고 있기 때문이라고 설명하고 있다. 또한 실 제 인장응력기로 탄성계수와 인장강도를 측정하여 3차원 $\mathrm{Al}_{2} \mathrm{O}_{3} /$ 에폭시 복합소재는 기존에 보고된 그래핀, 탄소나 노튜브 등의 초고강도 필러 재료를 이용한 에폭시 복합소 재들과 유사한 강화효과를 보인다. 저자들은 이를 통해 그래핀보다 100 배 정도 약한 $\mathrm{Al}_{2} \mathrm{O}_{3}$ 에 3 차원 구조를 접목 하여 높은 필러 첨가비까지 강화효과를 확장하면 초고강 도 소재와 비견할 수 있는 복합소재를 제조할 수 있다는 것을 증명했다. (그림8d) 마지막으로 만약 초고강도 소재 를 3차원 나노 구조화 시킬 수 있다면 기존에 보고된 고 분자 복합소재의 성능을 뛰어넘는 강도 또한 구현할 수 있을 것이라 기대된다.

\section{3 에너지 생산 및 저장 소재}

3 차원 방향으로 정렬된 다공성 구조의 기능성 세라믹 재료들은 기존 나노 재료들이 가지는 넓은 표면적이라는 장점뿐만 아니라 효율적 물질 전달 효과, 높은 전기전도 성, 독특한 기계적, 광학적 물성 등 다양한 특징들을 나
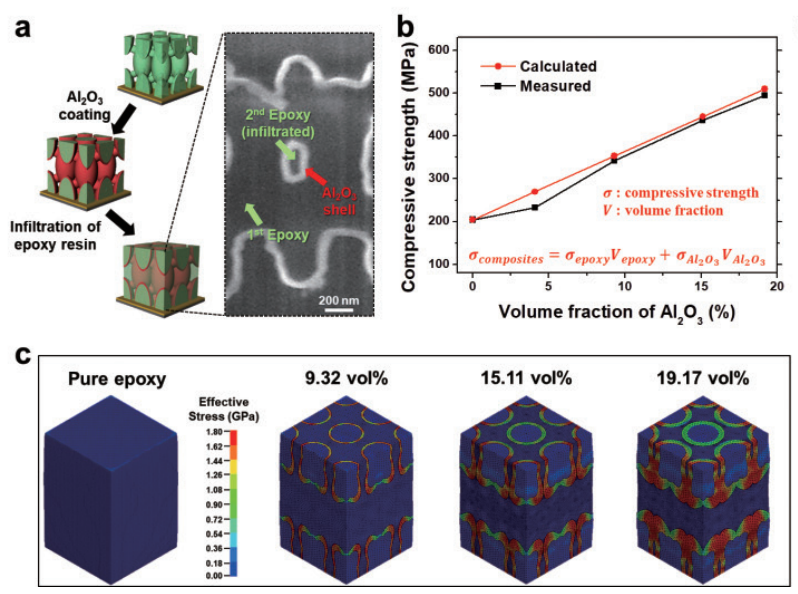

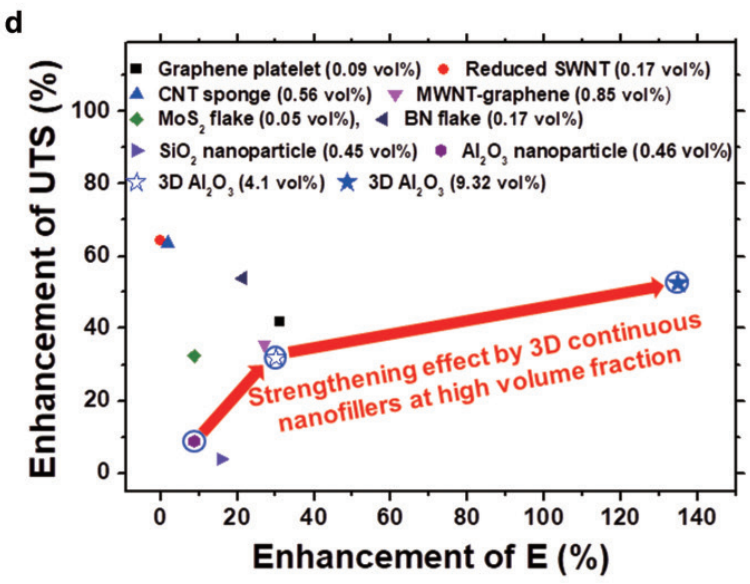

그림 8. $3 \mathrm{D} \mathrm{Al}_{2} \mathrm{O}_{3}$ 기반 고강도 고분자복합소재. (a) $3 \mathrm{D} \mathrm{Al}_{2} \mathrm{O}_{3}$ /에폭시 복합소재의 제작공정 및 단변 $\mathrm{SEM}$ 이미지, (b) $\mathrm{Al}_{2} \mathrm{O}_{3}$ 첨가량에 따른 복 합소재의 이론적, 실험적 압축강도, (c) $3 \mathrm{D} \mathrm{Al}_{2} \mathrm{O}_{3} /$ 에폭시 복합소재의 압축응력에 따른 응력분포, (d) 고강도 입자 기반 에폭시 복합소 재와의 탄성계수 및 인장강도의 향상치 비교 ${ }^{2}$ 
a

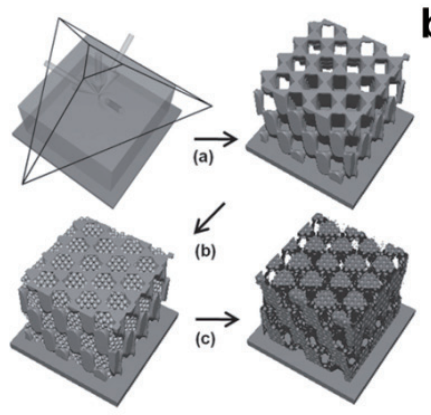

d

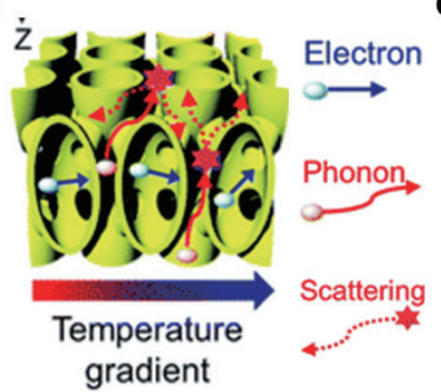

b

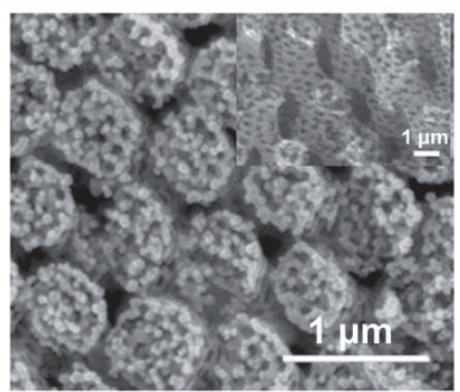

e

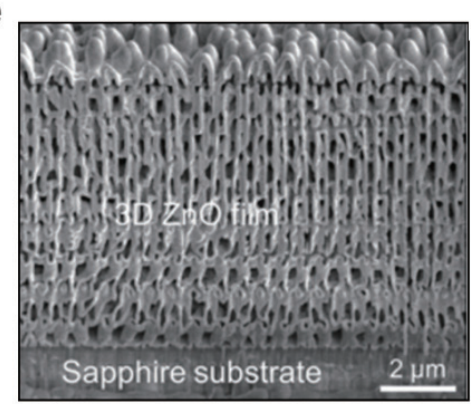

C

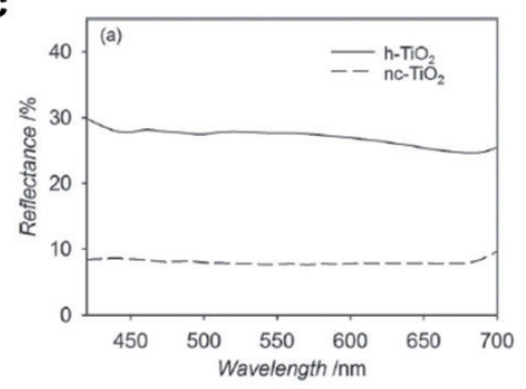

f

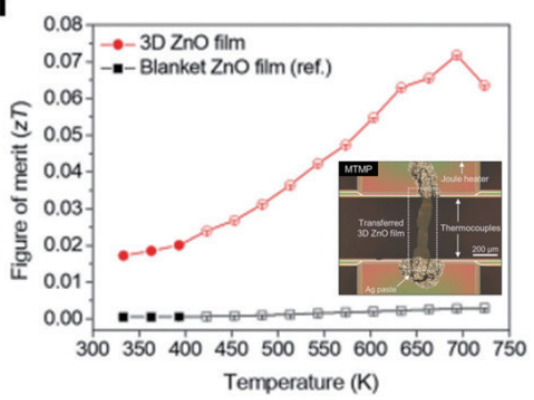

그림 9. 3D 세라믹 기반 경량 에너지 생산 소재. (a) $3 \mathrm{D}$ 계층적 나노 구조의 $\mathrm{TiO}_{2}$ 제작 공정 모식도 및 (b) SEM 이미지, (c) 반사도, (d) 3D ZnO 열전소재 모식도 및 (d) SEM 이미지, (f) 열전성능(Figure of merit, zT) (inset: 열전도도 측정 모듈) $)^{13-14}$

타냄으로 에너지 생산 및 저장 소재에 활용하려는 시도 또한 계속되고 있다. 특히, 이 절에서는 태양전지, 열전 소자, 리튬이온배터리에 3 차원 나노 구조의 기능성 세라 믹 소재들이 적용된 연구 결과들을 소개하고자 한다.

\subsection{1. $3 \mathrm{D} \mathrm{TiO}_{2}$ 기반 태양전지}

영구적인 에너지원인 태양광을 활용하여 에너지를 생 산하는 태양전지는 차세대 기술로써 각광받아왔고, 특히 가격이 저렴하고 상대적으로 높은 광-전기 변환 효율을 보이는 염료감응형 태양전지(Dye-sensitized solar cell, DSSC)는 보급형 태양전지 기술로써 많은 관심을 받 아왔다. 문준혁 교수 연구팀은 3차원 방향으로 정렬되고 계층적 기공 구조를 갖는 $\mathrm{TiO}_{2}$ 전극을 제작하여 염료감응 형 태양전지에 적용한 연구결과를 보고하였다. ${ }^{13)}$ 연구팀 은 multi-beam interference를 이용하여 수백 나노 크 기의 기공을 가진 3 차원 구조의 고분자 주형을 제작하고 기공 내부에 $50 \mathrm{~nm}$ 크기의 $\mathrm{TiO}_{2}$ 콜로이달 입자를 충진 시킨 후 고분자 주형을 $450^{\circ} \mathrm{C}$ 에서 선택적으로 제거함으 로써 3 차원 계층적 구조의 정렬된 $\mathrm{TiO}_{2}$ 전극을 제작하였
다. 제조된 전극은 수백 나노 크기의 정렬된 기공과 수십 나노 크기의 기공을 포함한 계층적 구조를 가지게 된다. ( 그림9a, b) 단순히 수십 나노 크기 기공만 포함한 나노 구 조 보다 계층적 나노 구조는 상대적으로 더 낮은 표면적 때문에 안료의 흡수량은 $30 \%$ 이상 더 적지만 에너지 변 환효율은 비슷한 수치(5\%)를 나타낸다. 이는 3 차원 방향 으로 정렬된 계층적 나노 구조의 $\mathrm{TiO}_{2}$ 전극의 높은 산란 효과와 짧은 이온 확산 거리 확보에 의한 재결합률 최소 화 효과에 따른 결과라고 보고하고 있다. (그림9c) 비슷한 성능을 $50 \%$ 적은 재료 소모량으로 구현할 수 있는 효율 적 접근 방법이라고 할 수 있다.

\subsection{2. $3 \mathrm{D} \mathrm{ZnO} \mathrm{기반} \mathrm{열전소자}$}

폐열을 이용한 열전소자 또한 인류의 에너지 확보를 위 한 미래 기술로써 연구가 활발히 진행되고 있으며, 발전 소에서 발생하는 고온의 폐열을 전기에너지로 전환하는 기술에 대한 관심이 집중되고 있다. 열전 성능을 나타내 는 Figure of merit 식은 아래와 같다. 


$$
\mathrm{zT}=S^{2} \sigma T / \kappa
$$

$S$ 는 seebeck coefficient, $\sigma$ 은 전기전도도, $T$ 은 절대 온도, $\kappa$ 는 열전도도를 나타낸다. 열전 특성을 향상시키기 위해서는 열전도도를 획기적으로 감소시키는 것이 중요 하므로 대부분의 열전달 매개체인 포논(phonon)의 산란 (scattering)을 극대화하는 구조 및 조성 개발이 다각적 으로 진행되고 있다. 전석우 교수 연구팀은 $\mathrm{ZnO}$ 의 3차원 나노 구조화만으로 열전도도를 감소시켜 열전 특성을 향 상시킨 연구결과를 보고하였다. ${ }^{14)} 3$ 차원 나노 구조의 $\mathrm{ZnO}$ 열전소재는 $\mathrm{PnP}$ 기술과 $\mathrm{ALD}$ 를 이용하여 사파이어 기판 위에 제작되었다. (그림9d, e) 열전소재의 3차원 나 노 구조는 포논이 산란할 수 있는 계면을 극대화할 수 있 어 기공이 없는 $\mathrm{ZnO}$ 박막의 열전도도 $(135.5 \mathrm{~W} / \mathrm{mK})$ 보 다 $1 / 40$ 수준인 $3.6 \mathrm{~W} / \mathrm{mK}$ 의 수치를 가능하게 한다. 이 는 열전 성능 수치를 나타내는 Figure of merit(zT) 값을 도핑 등 다른 조성 변화 기술 없이 단순히 구조변화를 통 해서 $2.9 \times 10^{-3}$ 수준에서 0.07 로 향상시키는 새로운 접 근 방식이다.(그림9f)

\subsection{3. $3 \mathrm{D} \mathrm{Ni} / \mathrm{MnO}_{2}$ 기반 리튬 이온 배터리}

UIUC의 Paul braun 교수 연구팀은 3차원 금속 전극/ 세라믹 활성층 복합 나노 구조화 기술을 이용하여 고성능 의 리튬이온배터리를 구현한 연구결과를 보고하였다. ${ }^{15)}$ Colloidal self-assembly 기술을 이용하여 PS(poly styrene)로 구성되어 있는 3차원 나노 구조의 주형을 전 도성 금속 기판 위에 제작하고 전기도금기술로 니켈 금속
을 기공 내에 충진 시킨 후 PS 주형을 화학적 용액을 이용 하여 선택적으로 제거하여 역상의 3차원 나노 구조의 니켈 을 제작하였다. 다음 공정으로 니켈 구조 표면에 $\mathrm{MnO}_{2}$ 를 전기도금기술로 형성시켜 집전체(current collector) 및 활 성층(active layer)이 모두 3차원 나노 구조를 가지고 있는 새로운 개념의 배터리용 전극을 제작했다. (그림10a, b) 제 조된 3차원 나노 복합 구조 전극은 넓은 표면적, 최소화된 이온 확산 거리, 전면적에서 상호 연결되어 있는 전해질 형 태 때문에 효율적이고 빠른 이온, 전자, 반응 물질들의 반 응 및 전달을 가능하게 한다. 결과적으로 Paul braun 교수 연구팀은 2 분의 충전으로 $90 \%$ 용량을 충전할 수 있는 초고 속 충방전 배터리를 구현하는데 성공했다.

\section{3. 결론}

본 총설에서는 다양한 기능성 세라믹 소재들의 3 차원 나노 구조화 기술과 이를 통해 구현된 고성능 기능성 세 라믹 소재들을 실제 응용분야에 적용한 사례들을 정리하 였다. 3차원 나노 구조 소재는 넓은 표면적뿐만 아니라, 정렬된 다공성 구조에 의한 효율적 물질, 이온, 전자 전 달 능력, 상호 연결성 구조에 의한 높은 응력, 전기 및 열 전달 능력 등 다양한 장점들을 가지고 있다. 3 차원 나노 구조의 기능성 세라믹 재료의 우수성을 증명한 여러 연구 결과들 중 본 총설에서는 광촉매, 구조 소재, 에너지 생 산 및 저장 소재 등 대표적 응용분야에 대해 현재까지 개 발된 기술들을 정리하였다. 본론의 응용분야에서 3차원 나노 구조화 기술을 통해 제작된 기능성 세라믹 소재들의
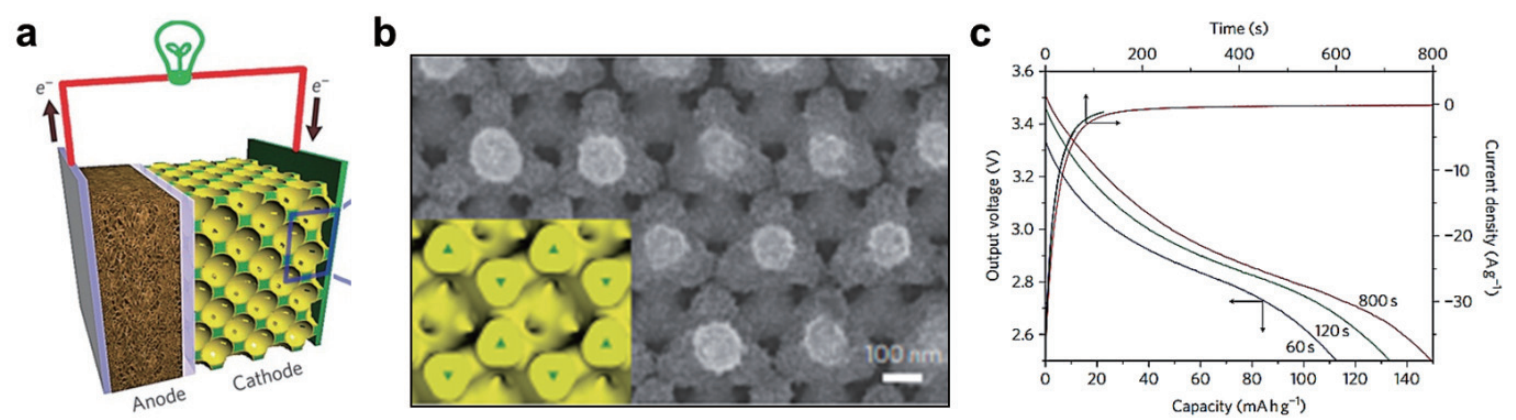

그림 10. 3D 세라믹 기반 경량 에너지 저장 소재. (a) $3 \mathrm{D} \mathrm{Ni} / \mathrm{MnO}_{2}$ 제작 공정 모식도 및 (b) SEM 이미지, (c) 배터리 성능 15 
특징을 간략히 다시 한번 설명하자면, 첫 번째, 3 차원 광 촉매 소재는 넓은 표면적과 정형화된 형태 특성으로 말미 암아 나노 입자와 광촉매 성능이 유사하고, 재사용이 용 이하며, 가시광 조사 하에서도 적용 가능하다는 것을 보 여줬다. 두 번째, 3 차원 나노 구조로 제작된 구조재료는 나노 수준에서 정렬된 구조적 특징 덕분에 낮은 밀도의 강도에서 기존 소재보다 크게 향상된 물성을 나타냈을 뿐 만 아니라 전면적에서 정렬 및 연결되어 있는 구조적 요 인에 의해 기존 소재의 강도 향상 효과를 뛰어넘는 이상 적인 복합소재를 구현할 수 있다는 연구결과를 보고했다. 마지막으로 주기적 기공 분포, 높은 비표면적 덕분에 태 양전지, 배터리, 열전소자를 포함한 고성능의 에너지 생 산 소자와 에너지 저장 소자 또한 구현할 수 있다는 것을 증명하는 연구 결과들을 소개했다. 본 총설에서 소개한 기능성 세라믹 소재의 3 차원 나노 구조화 기술은 높은 단 가, 낮은 수치 안정성 등의 현실적 문제들 때문에 실제 산 업계에는 적용되지 못하고 학계 위주로 연구개발이 진행 되고 있지만 정렬된 3 차원 나노 구조화 기술은 우수한 재 료 물성을 발현 시킬수 있는 미래 기술로써 기능성 세라 믹 기반 응용분야의 획기적인 성능 향상을 위한 하나의 대안이 될 수 있다. 특히, 대규모의 투자가 가능한 우주 항공 등 고부가가치 산업에서 우선적으로 적용하여 실제 산업에서의 가능성을 확인한 후, 인간의 삶과 가까운 실 생활에 보급하여 정착 시키는 것이 가장 현실적인 방법이 라 판단된다.

\section{참고문헌}

1. G. M. Gratson,M. Xu andJ. A. Lewis, "Microperiodic Structures: Direct Writing of Three-dimensional Webs,"Nature, 428[6981] 386 (2004).

2. Y. A. Vlasov, X. -Z. Bo, J. C. Sturm and D. J.Norris, "On-chip Natural Assembly of Silicon Photonic Bandgap Crystals," Nature, 414[6861] 289-93 (2001)

3. M. Campbell, D. N. Sharp, M. T. Harrison, R. G. Denning andA. J. Turberfield, "Fabrication of Photonic Crystals for the Visible Spectrum by Holographic Lithography,"Nature, 404[6773] 53-6 (2000)

4. S. Jeon, J. - U. Park, R. Cirelli, S. Yang, C. E. Heitzman, P. V. Braun, P. J. A. Kenis andJ. A. Rogers, "Fabricating
Complex Three-dimensional Nanostructures with High-resolution Conformable Phase Masks," Proc. Natt. Acad. Sci. U.S.A.,101[34] 12428-33 (2004)

5. J. Park, S. Wang, M. Li, C. Ahn, J. K. Hyun, D. S. Kim, D. K. Kim, J. A. Rogers, Y. Huang andS. Jeon, "Three-dimensional Nanonetworks for Giant Stretchability in Dielectrics and Conductors,"Nat. Commun.,3[916] (2012)

6. J. Ahn, C. Ahn, S. Jeon andJ. Park, "Atomic Layer Deposition of Inorganic Thin Films on 3D Polymer Nanonetworks,"Appl. Sci,,9[10] 1990 (2019)

7. C. Ahn, J. Park, D. Kim andS. Jeon, "Monolithic 3D Titania with Ultrathin Nanoshell Structures for Enhanced Photocatalytic Activity and Recyclability,"Nanoscale5[21] 10384-9 (2013)

8. K. Lee, H. Yoon, C. Ahn, J. Park andS. Jeon, "Strategies to Improve the Photocatalytic Activity of $\mathrm{TiO}_{2}$ : 3D Nanostructuring and Heterostructuring with Graphitic Carbon Nanomaterials,"Nanoscale,11[15] 7025-40 (2019)

9. S. Cho, C. Ahn, J. Park andS. Jeon, "3D Nanostructured $\mathrm{N}$-doped $\mathrm{TiO}_{2}$ Photocatalysts with Enhanced Visible Absorption,"Nanoscale,10[20] 9747-51 (2018)

10. D. Jang, L. R. Meza, F. Greer andJ. R. Greer, "Fabrication and Deformation of Three-dimensional Hollow Ceramic Nanostructures,"Nat. Mater.,12[10] 893-8 (2013)

11. Y. - E. Na, D. Shin, K. Kim, C. Ahn, S. Jeon andD. Jang, "Emergence of New Density-Strength Scaling Lawin3DHollowCeramicNanoarchitectures,"Small,14(44) 1802239 (2018)

12. C. Ahn, S. - M. Kim, J. -W. Jung, J. Park, T. Kim, S. E. Lee, D. Jang, J. - W. Hong, S. M. Han and S. Jeon, "Multifunctional Polymer Nanocomposites Reinforcedby3DContinuousCeramicNanofillers," ACS Nano,12[9] 9126-33 (2018)

13. C. - Y. Cho andJ. H. Moon, "Hierarchically Porous $\mathrm{TiO}_{2}$ Electrodes Fabricated by Dual Templating Methods for Dye-Sensitized Solar Cells,"Advanced Materials,23[26] 2971-5 (2011)

14. K. Kim, J. Park, S. Hong, S. H. Park, S. G. Jeon, C. Ahn, J.Y.SongandS. Jeon, "AnomalousThermoelectricity of Pure $\mathrm{ZnO}$ from 3D Continuous Ultrathin Nanoshell Structures,"Nanoscale,10[6] 3046-52 (2018)

15. H. Zhang, X. Yu andP. V. Braun, "Three-dimensional Bicontinuous Ultrafast-charge and -discharge Bulk Battery Electrodes,"Nat. Nanotechnol,6[5] 277-81 (2011) 


\section{특 집 묘 안창의, 박준용, 전석우}

\section{๑๐ 안 창 의}

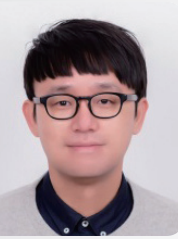

○ 2007년-2011년 성균관대학교 신소재공학부 학사

○ 2011년-2013년 한국과학기술원 신소재공학과 석사

○ 2013년-2018년 한국과학기술원 신소재공학과 박사

○ 2018년-2018년 한국과학기술원 응용과학연구소, 박사 후 연구원

○ 2019년-현 재 한국세라믹기술원 엔지니어링세라믹센터, 선임연구원

\section{ㅇ박 준 용}

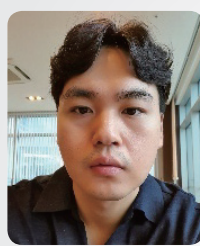

- 2005년-2009년 성균관대학교 신소재공학부 학사

0 2009년-2011년 한국과학기술원 신소재공학과 석사

○ 2011년-2015년 한국과학기술원 신소재공학과 박사

( 2015년-2016년 MIT 화학공학과, 박사후 연구원

( 2016년-2017년 한국과학기술원 응용과학 연구소, 박사후 연구원

( 2017년-2018년 한국과학기술원 신소재공학과 연구조교수

( 2018년-현 재 금오공과대학교 신소재공학부, 조교수

\section{•• 전 석 우}

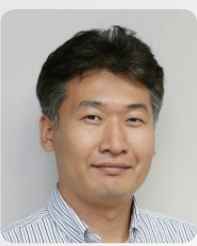

(- 1993년-2000년 서울대학교 재료공학부 학사

(0) 2001년-2003년 서울대학교 재료공학과 석사

○ 2003년-2006년 University of Illinois at

Urbana-

Champaign(UIUC)

재료공학과 박사

○ 2007년-2008년 Columbia University,

Nanoscale Science and

Engineering Center,

박사후 연구원

○ 2008년-2012년 한국과학기술원

신소재공학과,조교수

- 2012년-2018년 한국과학기술원

신소재공학과,부교수

○ 2018년-현 재 한국과학기술원

신소재공학과, 정교수 